\title{
The Place of the Region in IR
}

\section{Jessica da Silva C de Oliveira*}

\begin{abstract}
This article focuses on the problem of regarding regions as secondary features of the international/global dimension, and on the prevailing geopolitical imagery for thinking about and arguing with regions in IR. However, in contrast with the supposedly value-free vocabulary utilised for discussing regions in IR, the act of defining them in cartographic terms, or as a middle ground between national and international politics, is always a political one. In this article, I explore the politics of scaling in respect of regions and regional politics, and suggest that, if regions are understood as artifacts instead of self-evident entities fitting into a neat framework of levels, and disconnected from political struggles, this would assist the analysis and discussion of regions in theory as well as highlight other dynamics surrounding the complex and varied political projects, geographies and subjectivities that could be characterised as 'regional'.
\end{abstract}

Keywords: Region; Levels; Scaling; International Security; International Political Economy; Geopolitics.

\section{Introduction}

'Regional words' ... always reflect the regional worlds in which they have been developed. - Anssi Paasi (2002)

The post-cold War era brought new hopes, fears, and 'dreams of a world where everything has become part of one single imperial system' (Tsing 2005: xiii). This supposed triumph of the West is also intimately connected with the fragmented but all-encompassing process of globalisation. However, globalisation and its related processes are not as global (in the sense of universal) as some of its advocates believe it to be. This is because the postCold War era brought not only new forms of political, cultural and economic control, but also of inclusion and exclusion; differentiation and homogenisation in global dynamics. In this sense, it is not surprising that a renewed interest in arguing with regions and other spatial categories such as the local, the national, as well as the interplays among them (sometimes translated by the prefix 'trans-'), would bring with it a need to understand the dynamics of assimilation and differentiation (i.e. political identity[ies] and the politics of identity) in the context of globalisation and global connections.

* Pontifical University Catholic of Rio de Janeiro, Rio de Janeiro-RJ, Brazil; jessicascoliveira@gmail.com. 
IR scholars commonly argue that, in contrast with the previous overlapping bipolar structure of the international system, the end of the Cold War 'liberated' regions as an alternative platform for political action as well as a basis for a more graduated analysis. This view is shared by scholars active in international security studies (ISS) and international political economy (IPE) (Fawcett 1995; 2004; Buzan [1983]1991; Hurrell 1995; Hettne 2003; Väyrynen 2003; Buzan and Wæver 2003), who generally acknowledge that 'the importance of regional relations ha[s] expanded with the end of the Cold War, and that regions are a substantially more important venue of conflict and cooperation than in the past' (Lake and Morgan 2007: 7).

This study is motivated by an apparent contradiction in the literature of regionalism. On the one hand, IR scholars widely acknowledge the importance of the notion of region in contemporary geopolitical discourse, forming part of and interacting with the other spheres of social life - local, metropolitan, national, international and global - that play central roles in the post-Cold War world. On the other, they fail to interrogate the discipline's ways of mapping the world, or their implications for the notion of region and 'the politics of regionness' (Emerson 2014) - that is, the political struggles that mark processes of regionalisation or region-making in theory and practice. As John A Agnew (2013) has noted, IR scholars often use the term 'region' either to 'group together nations that are apparently similar and thus to simplify a greater complexity', or to situate IR studies in a 'meso-regional field of reference' (Agnew 2013: 13) that is larger than the national, and smaller than the international. Thus, while IR scholars often write about regions, they often fail to (re)think the region as a relevant category in both theory and practice.

Against this background, I re-examine the meaning and role of the region and regional politics in IR. First, I re-examine the notion of region in terms of the formative assumptions and categories of IR as a field of knowledge, often referred to as 'the level of analysis' problem and its neat discourse of scales (individual, state, international and global). Secondly, I argue that the limited gestures in both ISS and IPE towards the region, or what Guy R Emerson (2014) calls the 'politics of regionness' - problematised by John Agnew (2013), Pinar Bilgin (2005), Björn Hettne (2005), Klaus Dodds (2005), among others - is a symptom of a specific politics of scaling in IR. Even in work aimed at analysing regions and addressing their role as a social construct, they are dragged into a specific imaginary where scales are naturalised in terms of the nation-state and/or its verticalisation, the international, as a self-evident and sealed topography. Politics and transformation are understood in terms of this limited imagination; issues of scale and the political strategies and struggles over the meanings, practices and roles implied by these issues are erased from the picture.

In seeking to address this shortcoming, I connect the perspective on regions as analytical and practical artifacts suggested by the Brazilian geographer Rogério Haesbaert (2010a) with Ann Tsing's suggestion (2005) that we should examine social topographies (i.e. the regional, local and global) and their (dis)connections as issues of scale, or 'an ethnography of global connections'. This approach exposes the reification of geopolitical categories in the conventional discourse, and also casts light on the ways in which 'frictional' social encounters are artificially turned into (or displayed as) instances of coherence. 


\section{Regions, scale-making, and the discourse of the international}

In his discussion of the birth of the discipline of IR, Robert Vitalis (2005) reminds us of Raymond L Buell's 'man in the moon' trope for understanding the point of view of a discipline (and the role of its professionals) whose 'specialized object of knowledge' is usually taken to be 'the state system'. Looking down from the privileged standpoint of the moon's surface, the man could observe the 'world island' and its 'smaller islands' such as North America, intrigued by the social organization of the ant-like men' (Vitalis 2005: 159). Vitalis quotes an interesting paragraph from Buell's book International Relations (1925):

If this other-world spectator is not color-blind, he would find that these men are of different hues - in Europe and America, what are called 'white men', but in oriental Asia, 825,000,000 beings who mostly are yellow and brown. Beneath the dense foliage of the mysterious continent of Africa, he would see the home of the black man[...] If the Man in the Moon should gaze long enough, he would find that these ant-like men differ not only in physical characteristics, but in material and mental accomplishments.

If the Man in the Moon had a political bent, he would soon learn that mankind had split itself into a large number of groups, some of which are called states, other, nations, and still others races (Buell 1929: 3-4, quoted in Vitalis 2005: 159-60).

Vitalis's approach not only brings to the fore the politics of the discipline's characteristic historical narrative about its own birth and the birth of its main traditional object of knowledge, the state system (i.e. the myth of Westphalia), but also calls into question the very notions of scales, boundaries, and boundary-making that informed its birth (i.e. IR as a field concerned with spaces external to the USA, but one that reflected much of the everyday anxieties of American society at that time). For our purposes, however, the 'man in the moon' trope effectively illuminates the notion of region as normally used in IR literature. It condenses both the discipline's usual reliance on the 'God's eye view' - a common approach in classical geopolitical reasoning that denotes a belief in the possibility of offering a 'view of nowhere', or a 'disembodied' spectator theory of knowledge when addressing social phenomena (Vitalis 2005) - and the closely related imaginative geographies, to use Edward Said's (1994) terminology, that sustain most of the discipline's maps of the world as well as its methods of mapping the world, where the demarcation of geographical regions, the understanding of them as territorial entities sealed off around pristine cultures, and a hierarchical differentiation among them play a crucial role.

This section represents the first part of my attempt at approaching the region as a topology of knowledge and practice in IR - in other words, how the region appears as an analytical device for understanding world politics. I argue that the region, as a spatial category, is intimately connected to a specific 'politics of scaling', to paraphrase Ann Tsing's 
(2005) work, marking IR's dominant theoretical assumptions about how politics occurs in space, and, in consequence, what its limits are, and where they are placed.

Despite its manifold uses and misuses inside and outside academia, 'region' remains a crucial concept for understanding and describing social and political life (Paasi 2002). As a consequence of its amplitude not only as an analytical category but also one marked by more commonsensical definitions that are grounded in but also constantly disrupted by the frictions of everyday language and practices, the geographer Rogério Haesbaert addresses the region as a 'polysemous' concept (2010a: 20). The broad but meaningful discussion in his recent book, Regional-Global (Haesbaert 2010a), about the place of the region in the era of globalisation and the manifold articulations of the global, invites the reader to (re)consider the region's ambivalent nature as both analytical concept and lived geography - the notion of regions as artifacts. It recognises that, as an analytical concept, the region has the potential to ordinate, totalise and/or homogenise spaces, contexts, themes and individuals. Besides this conceptual dimension, the region is also mobilised as a sphere of action by social actors in many different senses and contexts (Haesbaert 2010a; 2010b; also see Paasi 2002; Emerson 2014). What is not usually acknowledged, however, is that the relevance of the region as an 'analytical construct', or 'artifice' - therefore, an abstraction that can be turned into a 'fact' or chains of facts about places, societies, and individuals - is not devoid of importance as an indicator and enabler of directions and political strategies. By acknowledging the complexity of this dual nature of the region, Haesbaert advocates an understanding of regions as 'artifacts':

[T] he region/regionalization as arti-fact - an expression that seeks to simultaneously combine both the 'factual' dimension or, in a broader sense, its quality as phenomena (something that goes beyond the often highlighted material dimension, and that also comprises the conceptions of symbolic and 'lived'), and its 'artificial' character, or, as in a non-dichotomous perspective, the region's constructive/constructivist character. [T] he word 'arti-fact' (or, if we like, artifact) manages to successfully synthesize this ambivalence or, in other words, this relational nature of the regional space (Haesbaert 2010a: 95-6, my translation).

Among the multiple conceptions of regions that Haesbaert retrieves in his examinations of the regional theme $(2010 \mathrm{a} ; 2010 \mathrm{~b})$, it is possible to discern a fundamental characteristic, namely the notion of the region as 'a cutting of the space, at multiple scales'. The connection of the region with scale-making is thus present in various areas of human knowledge, from biology and medicine (i.e. regions of the human body), to the Earth (climate, geopolitical, economical regions) and the way it encourages a totalising but also a multi-scaled perception of a range of social topologies, 'moving from the urban to the subnational or provincial, supranational and continental' (Haesbaert 2010a: 23; 20-5).

The discourse of scales is thus a common point in this mosaic of images and the cacophony of narratives about the region. Scale-making, however, is neither God's work, 
nor something that occurs in a political vacuum. I resort to Ann Tsing's insightful remarks about what she calls 'the politics of scale-making':

Scale is the spatial dimensionality necessary for a particular kind of view, whether up close or from a distance, microscopic or planetary. [...] [S]cale is not just a neutral frame for viewing the world; scale must be brought into being: proposed, practiced, and evaded, as well as taken for granted. Scales are claimed and contested in cultural and political projects. A 'globalism' is a commitment to the global, and there are multiple, overlapping, and somewhat contradictory globalisms; a 'regionalism' is a commitment to the region; and so on. Not all claims and commitments about scale are particularly effective. Links among varied scale-making projects can bring each project vitality and power. The specificity of these articulations and collaborations also limits the spread and play of scale-making projects, promising them only a tentative moment in a particular history (Tsing 2005: 58).

If scales and, by analogy, the region itself are constructed and contingent, as maintained by both Haesbaert, with reference to Moore (2008), and Tsing, albeit in different ways $^{1}$ - then 'they both are also objects of social and political disputes; they are continually responding to them' (Haesbaert 2010a: 94, my translation). Instead of focusing on fixity, continuity and distancing in her discussion of global connections, Tsing (2005) problematises the imagery of 'global coherence' that is usually privileged in popular accounts of the spread of the market economy and western liberal democracy (with Francis Fukuyama and Thomas Friedman as emblematic examples). Instead, she reminds us of the need to look to 'discontinuity and awkward connection, as this proves to be key to emergent sources of fear and hope' (Tsing 2005: 11), marking the diversity of globalisms, regionalisms and localisms, and the scale-making projects in which they are embedded.

This intimate relationship between region and scale-making contain fundamental linkages between the classical discussion in which IR's problematic Eurocentric spatial assumptions and its reliance on a language of levels, and the constant reproduction of a state-oriented geometry and the treatment of regions in IR - something Rob Walker (1993) has called 'the theme of Gulliver'. By drawing on Jonathan Swift's eponymous tale of misadventure dating from 1726, Walker argues that IR theory displays its limits in its conception of space (and time), for, regardless of its magnitude or scale, space is always conceived as apolitical, a constant feature, or a simple background to the objective laws of human relations. Even though IR itself was born as a discourse of scales - a field of knowledge aimed firstly at studying the inter-national, but one that has constantly been forced to adapt itself to the dynamics of the global, and the interplays among these and other topologies - this politics of scale-making is constantly effaced by an understanding of the international and any other levels or scales as self-evident, constant, absolute, and homogeneous. In this rationale, '[s] cales ought to fit neatly inside each other, the small in- 
side the large, each neutral and fully encompassed by the next scale up' (Tsing 2005: 104). Scale-making is thus effaced by an appearance of neutrality that prevents gazing beyond coherence, and asking how scales come into being through struggles over meaning, roles, and what should be privileged or not in the first place - or, in other words, how coherence is built by silencing the frictions that necessarily mark social encounters, and constitute their political and ethical results (Tsing 2005). The level-of-analysis debate in IR is thus imbued with such a problematic, but its rationale is also the condition of possibility (ontologically and epistemologically) for this type of assumption about the way in which social relations evolve in space and time. ${ }^{2}$

This relates to Phillip Darby's critique (2006) of the 'discourse of the international', which is close to what Bigo and Walker (2007) identify as 'the problem of the international', for it tends to favour the general, systemic and perennial - one of the explanations of the difficulty in addressing other geo-historical articulations without resorting to the nation-state topos. As famously acknowledged by Rob Walker (1993), the nation-state, as well as its verticalisation, the international, are strong and persistent expressions of the modern solution to the problem of locating politics and society. They are deeply rooted components of the modern imaginary of society and, broadly speaking, of how social relations are conducted in space and time. In this sense, the most common frame of reference in contemporary international thought is the world of sovereign nation-states and the limits of the interaction between these entities - i.e. the international. In consequence, everything that cannot be captured by this general discourse is automatically relegated to its margins, and obliterated (see Ashley and Walker 1990).

In this sense, John Agnew's bold assertion in a recent article in Regional Studies (2013) that regional politics is usually conceived in IR analysis as an artifice either 'to group together nations' by an apparent similarity 'and thus to simplify a greater complexity' or to ground international relations research within a 'meso-regional field of reference' seems to make sense. It connects well to this problematisation of the discipline's conception of scales and scale-making, which is connected in turn to the discourse of the international in its tendency to privilege verticality and neat conceptualisations of boundaries, political identity, and how politics supposedly happens within and between sealed levels of interaction on the one hand, and the triumphant geographies, to use Shapiro's (1999) words, such imaginary entails on the other. It is also an invitation to revisit and rethink the treatment of regions by a discipline that is meant to address the multifarious dynamics and features of the ever changing worlds of global politics, but usually does so without questioning the violent traits of its own fundamental concepts and geographical imaginaries.

\section{The place of the region in ISS and IPE}

Regions are deeply rooted in IR's geographical and geopolitical imaginary and language. However, a renewed and stronger interest in arguing with regions emerged in the aftermath of the Cold War, probably due to anxieties over transitions, over what the emerging world order would be, and how it should be approached by high-level politicians as well as academics. While post-Cold War ISS has centred on theoretical efforts and concepts 
such as 'regional security complex', 'regional order', and 'security community' in order to understand security dynamics in the regional level (Buzan and Wæver 2003; Lake and Morgan 2007; Morgan 2007; Katzenstein 2005; Adler and Crawford 2002), IPE scholars tend to focus on the neoliberal forces of globalisation, especially on how they shape and are shaped by processes of regionalisation (Mayall 1995; Hveem 2006; Stubbs and Reed 2006). In this literature, the region is usually depicted as a scale located in the interplays of the restructuring of national economies and national security in the face of globalisation, in which institutional initiatives may or may not happen, but where it is possible to find a constellation of forces, practices and social actors from different levels operating in such a way that proximity becomes relevant and generates senses of identification as well as particular patterns of interaction and differentiation in the face of other spatialities and geographic areas (Hameiri 2013; Emerson 2014; also see Haesbaert 2009).

This section thus pays due attention to how the regional theme has been articulated in ISS and IPE, and how, despite the fact that each field focuses on different aspects of IR, these literatures intersect in important ways when placing the region in this discipline. I argue that even though the region has been depicted as a relevant topology for understand change and, for some, an acute alternative to address contemporary confusions (or frictions) in the realms of world politics, it replicates an already scaled discourse or imagery, namely the international - or, following Darby (2006), the discourse of the international - and its limited understandings of politics, identity and transformation. Even when problematised, the region tends to be caught in a politics of scaling in which scales are naturalised by the imagery attached to either the nation-state and/or its verticalisation - the international - as self-evident, coherent and sealed topologies. Politics and transformations in politics can only be understood by resorting to this (limited) imagination. In the process, scale-making and the political strategies and struggles over meanings, practices and roles it implies are erased from the picture.

The concept of the 'regional security complex' (RSC) is a good example of a theoretical effort that has culminated in a common language for addressing the region as a relevant scale in which security interdependencies emerge more fiercely after the end of the Cold War (Buzan 1983; 1991; Lake and Morgan 1997; Buzan, Wæver and De Wilde 1998; Buzan and Wæver 2003). Although scholars have used this conceptual framework in different ways since it was first set out by Barry Buzan in the first edition of People, States and Fear (1983), RSCs are broadly understood as structures with mediating impacts on the dynamics of power in the international system. In other words, RSC is aimed at analysing how international security is clustered into geographically shaped regions, and how it relates to the systemic structure of power. The regional is characterised as the level on which national and global security extremes overlap, and is therefore the place, a sort of middle ground, where the most relevant security dynamics tend to occur (Buzan and Wæver 2003).

In Regions and Powers, for example, Buzan and Waever (2003) strongly rely on cartographic representations of regions, and the borders of various RSCs. Although RSCs are theorised as contingent to the diversity of security dynamics and perceptions and prac- 
tices of security by social actors (mostly state actors), a quick look at the book's maps and figures reveals that RSCs reflect a geopolitical representation of a world centred on nationstates - divided in superpowers, medium powers, and weak and failed states - and their interactions under structures of rivalry, conflict formation, containment, intervention, co-operation, and/or integration. Such structures, in turn, culminate in the imagery of 'key [geographical] areas' identifiable in terms of degrees of security and insecurity within regions, and the more or less acknowledged repercussions of these regional dynamics for the bigger picture of global security. Nonetheless, questions such as what is global security, who decides what is global security, 'for whom security becomes a consideration, and to whom' (Buzan, Wæver and De Wilde 1998: 16) - or even, what does 'global' really mean when one is talking about threats, danger, and (in)security in international politics from a particular stand or locality - are not seriously problematised in these terms (see Bilgin 2005).

A more inward approach towards the region can be found in the conceptualisation of 'security communities'. Pluralistic security communities are defined as 'transnational regions comprised of sovereign states whose people maintain dependable expectations of peaceful change' (Adler and Barnett 1998: 29, cited in Adler and Crawford 2002: 9). Social actors' shared perceptions of (in)security issues lead to the construction of senses of identification which, in turn, will shape the collective imagination of regional space and the possibilities of collective arrangements for peace (or at least peaceful change). Nonetheless, although Adler and Crawford (2002), and others working on this framework of security communities, seek to depict regions as socially constructed phenomena, this social dimension in the imagination and construction of regions - as well as of 'community' and 'identity' construction - seems to be a prerogative mostly of state actors, or social actors acting on behalf of the state. For a security community is 'a matter of mutual identity and loyalty, a sense of 'we-ness', or a 'we-feeling' among states (Adler and Crawford 2002: 9).

In this sense, RSC and related frameworks seem to carry the paradox of being (supposedly) universally applicable by the analyst, whereas s/he is trying to acknowledge particularities, and explain the particular contexts of things (see Acharya 2005; Teti 2007). The region is thus a self-evident level that is distinguishable from domestic, international and global levels, while replicating a similar logic of antisocial interaction as in-between and among those levels. In the region, international politics also seems to happen the way it is supposed to happen. This all-encompassing ambition of covering the 'radical diversity of security dynamics in different parts of the world' (Buzan and Waever 2003: ii) is thus exemplary of the 'top-down, outward-directed and military focused' (Bilgin 2005: 3) and generalising approach (even when a broader understanding of security is at play) that is broadly present in the literature on regional security, especially with regard to some parts of the globe. Thus, although the view of world politics as centred on the conflicts and preferences of the great powers has been constantly challenged, discussions of regional and global orders are still inflated with the strategic language of conflict management and intervention by the great powers as the main keepers of regional and global order, as well as with outwardly directed ways of measuring self-management (or the lack of it), conflict propensity, and prospects of co-operation in different regions. 
As regards those approaches focused more specifically on the role of the region in international and global political economy, attention is drawn to the study of regional patterns of interaction and/or integration as both catalysts or obstructers of the competitive dynamics of neoliberal globalisation. In what touches specifically on the place of the region or its quality as a geographical scale amid a web of relationships and processes identified under the umbrella term 'neoliberal globalisation', despite a vivid debate acknowledging the relevance, and addressing the roles, of many different social actors within the dynamics of globalisation and regionalisation (Fawcett 2004; Stubbs and Reed 2006), the prevalence of the state and its designation as the conventional unit of analysis is not only highlighted but still very powerful in this literature (Dicken 2002; Gilpin 2001). The region is usually depicted as a level of action articulated by states or state-led actors (Dicken 2002; Gilpin 2001; also see Hameiri 2013). Accordingly, the study of regionalism and regional integration - i.e. a more consciously driven process of regionalisation, 'which implies a policy whereby states and non-state actors cooperate and coordinate strategy within a given region' - is a recurrent framework in which the region is addressed (Fawcett 2004: 433).

Regionalisms are normally examined through two different but not mutually exclusive lenses - one more concerned with the projection of elite struggles onto an institutional and bureaucratic level that is on a scale above the state; and another that takes the shape of a smaller replica of the geopolitics of inter-state bargaining for gains (Hveem 2006; Gilpin 2001; Hameiri 2013). In some approaches, a greater degree of regionalisation can even culminate in a conception of the region as an acting subject itself, equipped with a distinct capacity of action, legitimacy, and a structure for decision-making (Hettne and Söderbaum 2002; Hettne 2003; Paul 2012). The EU is the most common reference, and its model of integration is usually pointed out as the telos of new regionalism (Väyrynen 2003). The European model is usually taken as normative benchmark in accounts on regional economic and security orders, where degrees of regional integration (e.g. presence of institutions, interdependence in different areas, and collective identity) are put in a continuum mode of disposition with a generalising and hierarchising effect over different regional contexts and regional orders (see Paul 2012). In this rationale, another common symptom is tracing analogies (sometimes in a loosely and supposedly un-problematically way) between degrees of regionality and degrees of stateness or nationess, in order to denote higher and deeper levels of integration (Hettne and Söderbaum 2002: 39).

Ultimately, it seems irrelevant whether regional systems are 'miniature anarchies in their own right' operating in analogy to the full international system, its laws and processes, its patterns of interaction among relevant actors, and its fortuity with regard to change (Buzan, Wæver and De Wilde 1998: 13), or as inherently 'open systems' that suffer major impact from ' $[\mathrm{t}$ ] he global system, other regional systems, and even 'outside' states' (Lake and Morgan 2007: 8-9). Subjected to the language of levels in IR, as if such semantics was a neutral, value-free instance or simply an analytical attitude, and disconnected from other discursive realms, such as geopolitics, development, and security, the region is taken for granted as a self-evident level or scale. Even when regions are understood as 
socially constructed entities that take on meaning and importance because social actors perceive themselves as cohabiting a common space and somehow sharing a common future - in other words, even when the region is problematised - IR manuals about regions and regional politics are nurtured by old cartographies that 'reproduce the state-centric structure of global recognition' (Shapiro 1999: 159) as well as by western-centric views of order, security, economy, and related notions of success and failure, safety and danger, peace and conflict (see Bilgin 2005; Dodds 2005).

The region and regional politics are thus problematised; indeed, most of the new literature on regions and the new regionalism tries to address their socially constructed character, although usually in an instrumental way that mirrors the replicating frame of 'the pursuit of material interest and/or efficiency' by state-led actors (Emerson 2014: 560). However, when it comes to social topologies, or to how scales are constructed and prevail over other scaling possibilities, the nation-state - in its broader role as a structure of recognition of how political identity and political relations evolve - is still ubiquitous. The making of regions - or the politics of scaling at play in region-making - is rarely addressed beyond such a regime of recognition. This constitutes the politics of scaling in IR, and how it tends to operate in respect of the notion of region.

When combined with the discussion in the previous section, one can begin to see how the region, as a spatial metaphor, is subordinated to what Bigo and Walker (2007) have referred to as 'the problem of the international. That is to say, the discourse of the international not only marks a field of knowledge, but also provides the dominant framework used by IR analysts for dealing with regions, as well as other complex forms of social relations and lived geographies.

\section{Triumphalist geographies and friction in the making of regions}

This section focuses on the political implications of the persistent problem of the region as a shadow of the international/global, and the prevailing geopolitical imagery for thinking about and arguing with regions in IR. In contrast with the supposed objectivity of the vocabulary usually adopted in IR approaches to the region, a close reading of this literature and critical accounts focused on similar problematic assumptions in geopolitics shows that the act of delimiting regions, even featuring them as mere cartographic representations, or a middle-ground stage between national and international politics, is always a political one. This is one way of exposing the politics of scale-making in which the theme of the region is invariably embedded. Another way is to problematise some of the political and ethical effects of 'triumphalist geographies' (Shapiro 1999) and the related 'geopolitics of knowledge' (Mignolo 2012) marking the discipline's gestures towards places and societies outside the West (or the western-centric notions of politics), and focus on how the notion or category of the region has been central to these analytical and strategic endeavours. I conclude with a brief discussion of the possibility of embracing the perspective of regions as artifacts and, consequently, of exposing scale-making as political projects in order to address regions in their making and (re-/un)making. This, I believe, is one way of starting to delink from preconceptions of the region, but also, and more broadly, from inadequate 
assumptions about how space, agency, and positionality work in a world of frictions and unexpected (dis)connections. As acknowledged by Haesbaert (2010a: 10), regions and region-making are 'always amidst hegemonic and counter-hegemonic processes'.

In a sophisticated account of the persistent geographic imaginary of what we have come to call 'world politics', Michael Shapiro (1999) draws attention to how the historical narrative of the triumph of nation-states and its forgetfulness in respect of the countless violent colonial encounters that informed (and, one might argue, still informs) this 'triumph' are complicit with contemporary cartographic practices in their appearance of neutrality, their 'static geometries', and their 'impressions of timeless boundaries' (Shapiro 1999: 159). John Agnew (2002) has also contended that this modern geopolitical imagination that relies on powerful assumptions such as 'a God's-eye view of the world' - another metaphor that can be connected to Raymond L Buell's 'man in the moon' - is nurtured by processes and a vision associated with European colonialism dating back to the $15^{\text {th }}$ century (see Quijano 2008; Mignolo 2012). What spins out of these enduring colonial and imperial traces of geopolitics and geographical imaginaries it usually encourages is the reproduction of a geography of cultural difference (e.g. the separation between 'savages' with no right to property and no basis for nationhood nor subjecthood, and the 'civilized', who are eligible for the property of material goods and the property of truth). A state-oriented geometry (a sort of 'social and political normativity' organised around 'an univocal code' for how human subjects and human relations might be framed in space and time, and which privileges 'what is sedentary and disparaging and arrest[s] what moves or flows across boundaries') is another feature of this 'triumphalist' spatial-temporal narrative (Shapiro 1999: 162).

Following this same trail, Dodds (2005) has highlighted how the invention of the term 'geopolitics' came along with the argument - some would call it the modern rationale or imaginary - that it was possible to observe the world in its totality. Thus, 'the earliest texts of geopolitics reflected the belief that the European observer possessed the necessary intellectual and conceptual framework for viewing the world as an external and independent "object" (Dodds 2005: 28). In academic fields focused on human relations in space(s) and time(s), a common way of representing this world is by mapping its political spaces by means of cartographic exercises as well as through narratives about what space and politics are, and how their relationship evolves. This, however, is only half the story, for the positions of 'observer' and the 'object of knowledge' are also placed in the realms of scale-making projects in which disciplines and academic discourse are embedded.

To resort to Buell's metaphor once again, the image of the man on the moon, the observer, looking down at the 'world Island' and its surface neatly divided into territorial entities, and being intrigued by the view of 'the social organization of the ant-like men' inside these 'smaller islands', provokes an important issue. It relates to how societies and social structures, in their quality as objects of knowledge, appear as easily observable entities - sometimes resembling morsels of land, or pieces on a board game. From this perspective, the man in the moon metaphor effectively illustrates the imaginative geographies sustaining most of IR's spatial assumptions, its maps of the world as well as its exercises of mapping the world, and their portrayal as value-free engagements. It is also related to 'the 
political and ideological presuppositions underlying the philosophical' positioning that sustain most of Eurocentric myths - i.e. the belief that there is an 'absolute knowledge', a truth one must find and enunciate from this universal position of the 'knowing subject' who is devoid of all historical, religious, racial and gender configurations ('I think, therefore I am') (Mignolo 2012: xiii-xiv). Nonetheless, what these discussions focused on 'the truth' about objects in a 'mono-topic and homogeneous world' usually hide, as Mignolo (2012) reminds us, is their own geopolitical grounding. That is to say, there is a silence about the 'geopolitics of knowledge', to use Mignolo's own phrase, sustaining these imperial ideas of universal history and of a supposedly universal mode of seeing/being in the world.

This is germane to this discussion because it helps to reveal some of the foundations of the geo-historical discourses that contribute to hierarchical views of societies as well as world views that efface some geopolitical spaces in favour of 'an appearance of coherence' and truth (Tsing 2005). As highlighted by Pinar Bilgin (2005) in her insightful review of regional security in the Middle East - perhaps one of the world regions that are most taken for granted - 'prevailing approaches to regional security have had their origins in the [high] security concerns and interests of Western states' and other world powers (such as the Soviet Union during most of the $20^{\text {th }}$ century). According to Bilgin, one of the enduring political effects of this 'top-down' and outward conception of regions is the prevalence of the perspective of external powers and of security strategists and experts 'rather than regional states or peoples' (Bilgin 2005: 1-2; also see Dodds 2005; Teti 2007). This remind us that geographical representations of this kind do not occur in a political vacuum. Academic geopolitical discourse and its imaginative geographies are crucial to the construction of geographical significance for places and regions, which can be linked to wider material interests and ideological aims. Consequently, imaginative geographies are not static, but historically and politically informed. From this perspective, there is arguably a constitutive relationship between geopolitical inventions (such as the definition of regions of the world), and the everyday practices and discourses of academics and social actors - including those that are silenced in the interplays of these projects. We therefore need to consider the importance of approaches connecting the production of knowledge about regions, populations, or areas (i.e. area studies) with the diverse strategic aims that fomented this production in the first place (Gregory 2004; Acharya 2005; Bilgin 2005; Teti 2007), as well as to what has been effaced from the generalising portrayals these endeavours tend to produce.

As the two previous sections show, the geopolitical discourse that seems to prevail in IR and most of the field's depictions of regions and regional politics (with rare exceptions, and despite attempts and protestations to the contrary) is arguably influenced by modern geopolitical viewpoints 'in their desire to divide' and approach 'the world into large regions or zones' (Dodds 2005: 7, my emphasis). This view often underestimates complexity, historicity and interconnection because, if it does not eschew such complications, its 'maps and/or [limited] visions of global political space would be compromised' (Dodds 2005: 7). The artifice of the homogeneous space (i.e. an understanding of space as apolitical, an empty vessel waiting to be endowed with content) thus assumes a denotive role in 
the imaginative geography of the region in IR. In this logic, the region, once it is defined - via the analyst's observation of various dynamics, processes, and the interactions of actors (mostly states), and/or the discourse of these very actors - becomes a framed space wherein the modern imaginary about levels, authority and subordination, territoriality, inside and outside, and higher and lower metaphors will also take place (see Walker 2000).

In this sense, it can be said that the imaginative geographies of IR are nurtured by two views that, at first glance, seem to compete due to differences in their assumptions about objects and positionality, but actually reinforce each other, as both are nurtured by IR's dominant scale-making politics. To revert to the level-of-analysis problem and its related tensions, we see, on the one hand, a levels scheme that seems to privilege seeing from the level of individual actors (i.e. the region emulating the state and the logic of actors' behaviour) - in other words, an ontological individualism that forecloses the possibility of seeing larger social contexts and their structuring features. As recently posited by Inayatullah and Blaney, we are referring to approaches that acknowledge differences between and among units or individual actors only in terms of a naturalised 'hierarchy of capacities and potentialities' (2015: 905). From this logic, the task of the comparatist is not to stress similarities and asymmetry in co-constitution, but to highlight gaps while portraying difference as a lack capacity as well as a backwardness. In this sense, when the 'structuring features of the whole' are neglected and 'colonial rule and imperial domination' are obliterated, 'it is easy to treat non-Western inferiority (irrationality, backward cultures, and so on) as an explanation for the relative successes and failures of a flattened planet of autonomous units' (Inayatullah and Blaney 2015: 903).

The other viewpoint of this tale is the focus on the whole as a homogeneous, ahistorical and semi-apolitical space of interaction for these discreet, nearly pristine units. As noted previously, when the language of interaction and co-constitution is allowed into these approaches, it is usually grasped in terms of recognition of a growing interdependence among the economies and security of nation-states, due to the complex and interconnected nature of social, political and economic life in a time of globalisation. The social density of the international/global is only acknowledged through limited gestures towards a limited conception of 'social' as the faculty of a small number of actors - usually state actors or state-led actors - managing the interdependence brought about by their interactions.

The effect seems to be the same: an antisocial theory of social relations in which historical structures and particular (hi)stories are subsumed in favour of a theory of the general and the acceptable in a world of what Shapiro (1999) calls 'triumphalist geographies'. Put differently, the particularity of one (hi)story is usually assumed as universal, or a sole standard, whose enduring myths seem to replicate themselves by indulging an imperial gaze and an specific imaginative geography while suppressing others. In this frame, the problem of levels, when read in the context of its Eurocentric traces, seems to be one of the possibility for the region to become self-evident as a macro-entity that is a shadow of the international/global. Such a definition hardly allows us to take account of the plurality of visions, discourses, practices and world views regarding what regions are or should be that is to say, the plurality of regional words and regional worlds (Paasi 2002). 
As argued previously, the semblance of neutrality in the discourse of scales and levels in which the topologies of the international are embedded is politically loaded. It spins out of a politics of scaling that privileges specific dynamics, themes, actors, and a particular world view - or a particular way of seeing and knowing the world - and is connected to prior notions of world politics, political space, and subjectivity while silencing others. In this sense, even when scholars make serious attempts to question categories and concepts historically regarded as undisputed (including the region and its place in world politics), they can end up revaluing the same categories that are causing the problems they are trying to resolve (see Walker 1993). Nonetheless, when we address how coherence (or the appearance of coherence) is created in discourses/categories of knowledge as well as in the realm of global connections - i.e. when we try to expose the ways in which coherence is built - we find the realm of social encounters, of practices and world views converging and/or contesting one another. In other words, we find friction.

In a recent article aimed at addressing some of the ontological and practical challenges surrounding the region and regional politics in IR and contemporary global politics, R Guy Emerson (2014) brings to the fore what seems to be an honest attempt to address what I have referred to as the politics of scale-making in which regions are embedded, albeit in his own terminology. In his account of what he calls 'the politics of regionness' in Latin-American regionalisms from 1990s until the present, such as the Bolivarian Alliance for the Peoples of Our America (ALBA-TCP), the author shows, for instance, how the concepts of Patria Grande and Patria Chica [great(er) homeland and smaller homeland] informed the overlapping practices of space and identity and the production of Latin-Americanness beyond mere geographical reference. The junctions and disjunctions of spatial levels and imaginaries enable multiple affiliations and a more complex and flexible practice of spatiality, whereby the lived experience of regionness does not necessarily correlate with fixed boundaries' (Emerson 2014: 571). They create space for regional actors to operate within, but to also contest and transform, inter-subjective space and meaning. The institutionalisation of the discourse of Pacha Mama [Mother Earth] within ALBA-TCP as a discourse of indigenous socialism promoted by previously marginalised actors (and not by established state leaderships), for example, shows how 'historically excluded indigenous actors' who are 'traditionally seen as inconsequential to regional politics' could profit 'from a more radical, Bolivarian reading of Latin Americanness' (Emerson 2014: 572) in a sense that not only encouraged but also enabled their participation in political and social life. Therefore, in this framework, regional actors operate in intersubjective spaces, but can also resist, rearticulate and transform these spaces. Following this rationale, although the 'national' - and, of course, the 'international' - is the topos to which one seems to appeal to make sense of regions in IR and related approaches, one way of overcoming the plasticity of the level-of-analysis language is to acknowledge that 'the multiple discourses' and practices aimed at establishing 'boundaries and identifying structures' are also 'products of continual struggle and therefore reappraisal' (Emerson 2014: 560). To put to the terminology adopted here, they are all 'artifacts' (Haesbaert 2010a) enmeshed in the contingency of encounters and in the scale-making projects that may emerge and be articulated in the 
context of global connections (Tsing 2005) - the politics of regionness being one specific type of scale-making project in its commitment to regions.

An understanding of the region as 'artifact' thus helps to break 'the duality sometimes advocated between regions as mere analytical construction, and regions as a materialfunctional and/or symbolic product of individuals' actions and social processes' (Haesbaert 2010b: 7). It also articulates with our discussion of the politics of defining regions and, more specifically, the notion of region in some exemplary works about regions and regional politics in IR. As Escobar (1995) reminds us, turning societies into objects of knowledge and management is not a neutral endeavour. Thus, even when conceived as 'artifice' - a conceptualisation, an analytical construct - the region is an artifact.

\section{Final remarks}

An overview of the main assumptions and debates surrounding the regional theme suggests that the region is captured as a self-evident geographical entity suitably located between the national and the systemic. Besides its depiction as a middle-ground concept/ location, the region is also subordinated to the discourse of the international, a discourse that tends to rely on an almost mechanical and (supposedly) detached and value-free language of levels, as well as on the reproduction of a state-oriented geometry. The theme of the region and the ways in which regional politics are taken up in the context of globalisation and the (dis)connections it generates is thus influenced by an approach that can only think in scales, and in which scaling is subordinated by a notion of proximity that is always understood as proximity among states, or state-led actors and processes. Political struggles are effaced, or have to (re)articulate their terms in a way that is understandable inside this grammar, in a movement that ends up by rearranging the content but hardly the form. Within these nuances, a set of assumptions about scale remains. The region appears as a self-evident level, a particular location, and an object of analysis that can be easily distinguished from the domestic, international and global levels while always being in danger of replicating the same logic of antisocial interaction, between and among (but rarely across) these levels or scales.

By contrast, I would like to suggest that rethinking regions as artifacts might enable us to recognise that they can be captured by totalising narratives that depoliticise their character as constructed entities as well as the imaginative geographies enmeshed in and perpetuated by these narratives. At the same time, it helps us to recognise that, once defined through discursive struggles over meaning and their practical dimensions, regions can also be turned into enabling sources for (re)invention, insertion, and/or resistance by different social actors - i.e. they can be a platform for political projects and action. When the region is viewed not only as an analytical artifice but also an artifact it becomes a space for the performance of identities and political projects that can both/either reproduce and/or contest dominant structures in both scientific knowledge and everyday practice/ knowledge in significant ways. 
This may be an important route towards an account of what Edward Said (1994) once called 'contrapuntal geographies' - a perspective that allows us to look back to and take into account 'the cultural archive' and the necessity of reading it 'with a simultaneous awareness' of both the dominant 'history that is narrated and those other histories against which (and together with which) the dominant discourse acts' (Said 1994: 51) in order to unravel the fiction that sustains their epistemological separation. That is to say, an approach that gestures towards a recognition of those other geo-historical loci and those imaginative geographies that were/are subsumed under the triumphalism and forgetfulness that have been nourished and encouraged by modern geopolitical discourse.

\section{Notes}

1 Whereas Haesbaert is interested in retrieving the regional theme in the era of globalisation, Tsing concentrates on addressing global connections while problematising neat and reified divisions between local and global. She starts by problematising the politics of scale-making - in which the regional is invariably implicated - while Haesbaert addresses scaling only in terms of region-making.

2 Although the notion of levels has been an integral part of contemporary international thinking, there is no uncontested definition of levels in IR literature. The idea of level can denote scale, hierarchy, unit - in the sense of 'the thing to be studied' - delimitation, verticality, dualities between parts and wholes, or even the different 'layers' of interpenetrating contexts (Onuf 1998: 195). While David Singer (1961) speaks of two main levels (international system and national subsystems), Kenneth Waltz works with the equivalent idea of 'images' (individual, state and interstate system) in his Man, State and War (2001). In his thorough work on levels, Nicholas Onuf notes: 'Levels schemes are all members of a family of pictures, or framed spaces, within which we see the contents of the field of study we call international relations' (1995: 41). As he indicates, the language of levels is deeply entrenched not only in a specific vocabulary, but also in a specific way of seeing and making the world: 'Levels are not just a taxonomic convenience for scholars, or a methodological convenience. They are a potent metaphor, an ancient convention, for marking, and thus making, wholes. In our culture, as in our field, we would have difficulty getting along without the language of levels' (Onuf 1995: 53). Also see Onuf (1995: 35-58; 1998: 193-219); Singer (1961: 77-92); Waltz (2001).

\section{References}

Acharya, Amitav. 2005. 'International Relations and Area Studies: towards a new synthesis? (with special reference to Asia)'. Workshop on the Future of Interdisciplinary Area Studies in the UK, Oxford University. 6-7 December.

Adler, Emanuel and Beverly Crawford. 2002. 'Constructing a Mediterranean Region: A Cultural Approach'. Conference on the Convergence of Civilizations - Constructing a Mediterranean Region. Lisboa: Arrábida Monastery/Fundação Oriente. 6-9 June.

Agnew, John. 2002. Geopolitics. London: Routledge.

2013. 'Arguing with regions'. Regional Studies 47 (1): 6-17.

Ashley, Richard and Rob B J Walker. 1990. 'Speaking the language of exile: dissident thought in International Studies'. International Relations Quarterly 34(3): 259-68.

Bigo, Didier and Rob B J Walker. 2007. 'Political sociology and the problem of the international'. Millenium: Journal of International Studies 35 (3): 725-39. 
Bilgin, Pinar. 2005. Regional Security in the Middle East - A Critical Perspective. New York/Oxon: Routledge Curzon.

Buzan, Barry. 1991[1983]. People, States and Fear: An Agenda for International Security Studies in the Post-Cold War Era. Hertfordshire: Harvester and Wheatsheaf.

Buzan, Barry, Ole Wæver and Jaap De Wilde. 1998. Security: A New Framework for Analysis. London: Lynne Rienner.

Buzan, Barry and Ole Wæver. 2003. Regions and Powers - The Structure of International Security. New York: Cambridge University Press.

Darby, Phillip. 2006. 'Introduction'. In Phillip Darby (ed), Postcolonizing the International: Working to Change the Way We Are. Honolulu: University of Hawai'i Press.

Dicken, Peter. 2002. 'A new geo-economy'. In David Held and Anthony McGrew (eds), The Global Transformations Reader. Oxford: Blackwell. pp. 251-8.

Dodds, Klaus. 2005. Global Geopolitics - An Introduction. Essex: Pearson Education.

Emerson, Guy R. 2014. 'An art of the region: towards a politics of regionness'. New Political Economy 19(4): 559-77.

Escobar, Arturo. 1995. Encountering Development: The Making and Unmaking of the Third World. New Jersey: Princeton University Press. pp. 21-54.

Fawcett, Louise. 1995. 'Regionalism in historical perspective'. In Louise Fawcett and Andrew Hurrell (eds), Regionalism in World Politics - Regional Organization and International Order. Oxford/New York: Oxford University Press. pp. 9-36.

2004. 'Exploring regional domains: a comparative history of regionalism'. International Affairs 80(3): 429-46.

Gilpin, Robert. 2001. Global Political Economy: Understanding International Economic Order. Princeton: Princeton University Press.

Gregory, Derek. 2004. The Colonial Present. Massachusetts, Oxford: Blackwell.

Haesbaert, Rogerio. 2009. 'Dilema de conceitos: espaço-território e contenção territorial'. In Eliseu S Esposito and Marcos A Saquet (eds), Territórios e territorialidades - teorias, processos e conflitos. São Paulo: UNESP. pp. 95-120.

2010a. Regional Global - Dilemas da Região e da Regionalização na Geografia Contemporânea. Rio de Janeiro: Bertrand Brasil.

. 2010b. 'Região, regionalização e regionalidade: questões contemporâneas'. Antares: Letras e Humanidades 3: 1-24.

Hameiri, Shahar. 2013. 'Theorising regions through changes in statehood: rethinking the theory and method of comparative regionalism'. Review of International Studies 39(2): 313-35.

Hettne, Björn. 2003. 'Global market versus regionalism'. In David Held and Anthony McGrew (eds), The Global Transformations Reader. Oxford: Backwell. pp. 359-69.

2005. 'Beyond the "new” regionalism'. New Political Economy 10(4): 543-71.

Hettne, Björn and Fredrik Söderbaum. 2002. 'Theorizing the rise of regioness'. In Shaun Breslin, Christopher W Hughes, Nicola Phillips and Ben Rosemond (eds), New Regionalisms in the Global Political Economy. London: Routledge. pp. 33-47. 
Hurrell, Andrew. 1995. 'Regionalism in theoretical perspective'. In Louise Fawcett and Andrew Hurrell (eds), Regionalism in World Politics - Regional Organization and International Order. Oxford/ New York: Oxford University Press. pp. 37-73.

2005. 'The regional dimension in international relations theory'. In Mary Farrell, Björn Hettne and Luk Langehove (eds), The Global Politics of Regionalism - Theory and Practice. London: Pluto. pp. 38-53.

Hveem, Helge. 2006. 'Explaining the regional phenomenon in an era of globalization'. In Richard Stubbs and Geoffrey Underhill (eds), Political Economy and the Changing Global Order. Oxford University Press. pp. 294-305.

Inayatullah, Naeem and David L Blaney. 2015. 'A problem with levels: how to engage a diverse IPE.' Contexto Internacional 37(3): 889-911.

Katzenstein, Peter J. 2005. A World of Regions - Asia and Europe in the American Imperium. Ithaca/ London: Cornell University Press.

Lake, David A and Patrick Morgan. 2007. 'The new regionalism in security affairs'. In David A Lake and Patrick Morgan (eds), Regional Orders - Building Security in a New World. Pennsylvania: The Pennsylvania State University Press. pp. 3-19.

Mamadouh, Virginie and Gertjan Dijkink. 2006. 'Geopolitics, International Relations and Political Geography: the politics of geopolitical discourse'. Geopolitics 11(3): 349-66.

Mayall, James. 1995. 'National identity and the revival of regionalism'. In Louise Fawcett and Andrew Hurrell (eds), Regionalism in World Politics - Regional Organization and International Order. Oxford/New York: Oxford University Press. pp. 169-98.

Mignolo, Walter. 2012. Local Histories/Global Designs. Princeton/Oxford: Princeton University Press.

Morgan, Patrick M. 2007. 'Regional security complexes and regional orders'. In David A Lake and Patrick Morgan (eds), Regional Orders - Building Security in a New World. Pennsylvania: The Pennsylvania State University Press. pp. 20-42.

Onuf, Nicholas G. 1995. 'Levels'. European Journal of International Relations 1(1): 35-58.

The Republican Legacy in International Thought. Cambridge: Cambridge University Press. pp. 193-219.

Paasi, Anssi. 2002. 'Place and region: regional worlds and words'. Progress in Human Geography 26 (6): 802-11.

Paul, T V. 2012. 'Regional transformation in international relations'. In T V Paul, International Relations Theory and Regional Transformation. New York: Cambridge University Press. pp. 3-46.

Quijano, Aníbal. 2008. 'Coloniality of power, Eurocentrism, and Latin America'. In Mabel Moraña, Enrique Dussel and Carlos A Jáuregui (eds), Coloniality at Large - Latin America and the Postcolonial Debate. Durham/London: Duke University Press. pp. 181-224.

Said, Edward. 1994. Culture and Imperialism. New York: Vintage Books.

Shapiro, Michael J. 1999. 'Triumphalist geographies'. In Mike Featherstone and Scott Lash (eds), Spaces of Culture - City, Nation, World. London: Sage. pp. 159-74.

Singer, David. 1961. 'The-level-of-analysis problem in International Relations'. World Politics 14(1): $77-92$. 
Stubbs, Richard and Austina J Reed. 2006 'Introduction: regionalization and globalization'. In Richard Stubbs and Austina J Reed (eds), Political Economy and the Changing Global Order. Oxford: Oxford University Press. pp. 289-93.

Teti, Andrea. 2007. 'Bridging the gap: IR, Middle East studies and the disciplinary politics of the area studies controversy’. European Journal of International Relations 13(1): 117-45.

Tsing, Anna Lowenhaupt. 2005. Friction: An Ethnography of Global Connection. New Jersey: Princeton University Press.

Väyrynen, Raimo. 2003. 'Regionalism: old and new'. International Studies Review 3: 25-51.

Vitalis, Robert. 2005. 'Birth of a discipline'. In D Long and Brian C Schmidt (eds), Imperialism and Internationalism in the Discipline of International Relations. New York: SUNY Press. pp. 159-81.

Walker, Rob B J. 1993. Inside/outside: International Relations as Political Theory. Cambridge: Cambridge University Press.

2000. 'Europe is not where it is supposed to be'. In Morten Kelstrup and Michael Williams (eds), International Relations Theory and the Politics of European Integration: Power, Security and Community. London: Routledge. pp. 14-32.

Waltz, Kenneth. 2001. Man, the State and War. New York: Columbia University Press.

\section{Acknowledgements}

This article is a revised and extended version of the second chapter of my Master's thesis, and I am grateful to my supervisor, Carolina Moulin, for her honest and insightful comments. I would like to thank Paulo Chamon, Marta Fernández, and Thiago Rodrigues for their detailed feedback on various drafts. Lastly, I would like to thank the Contexto Internacional editorial team for their assistance, and the two anonymous reviewers for their patient reading and suggestions.

\section{About the author}

Jessica da Silva Correia de Oliveira holds a master's degree in International Relations from the Institute of International Relations of Pontifical Catholic University of Rio de Janeiro (IRI/PUC-Rio), Brazil. Her dissertation, 'Topologies and Imaginaries about the Region and the Maghreb as an Artifact: Capture, Insertion and Resistance', won the national prize for outstanding academic production of the Brazilian Association of International Relations (ABRI) in 2013. She is currently a PhD candidate at IRI/PUC-Rio, and has conducted part of her research at McMaster University, Canada. Her research interests include postcolonial/decolonial studies, global studies, and literature and narrative in IR, with an emphasis on the Maghreb region.

Received on 25 May 2016, and approved for publication on 14 September 2016.

\section{(c)) BY-NC} https://creativecommons.org/licenses/by-nc/4.0/ 
